\title{
SWEARING AND ITS MOTIVES \\ IN THE ANTOLOGI RASA NOVEL
}

\author{
Adityo Prawinanto \\ adityoprawinanto@yahoo.co.id \\ Sanata Dharma University of Yogyakarta, Indonesia \\ Hardi Prasetyo \\ hardi@iastate.edu \\ Iowa State University of United State \\ Barli Bram \\ barli@usd.ac.id \\ Sanata Dharma University of Yogyakarta, Indonesia
}

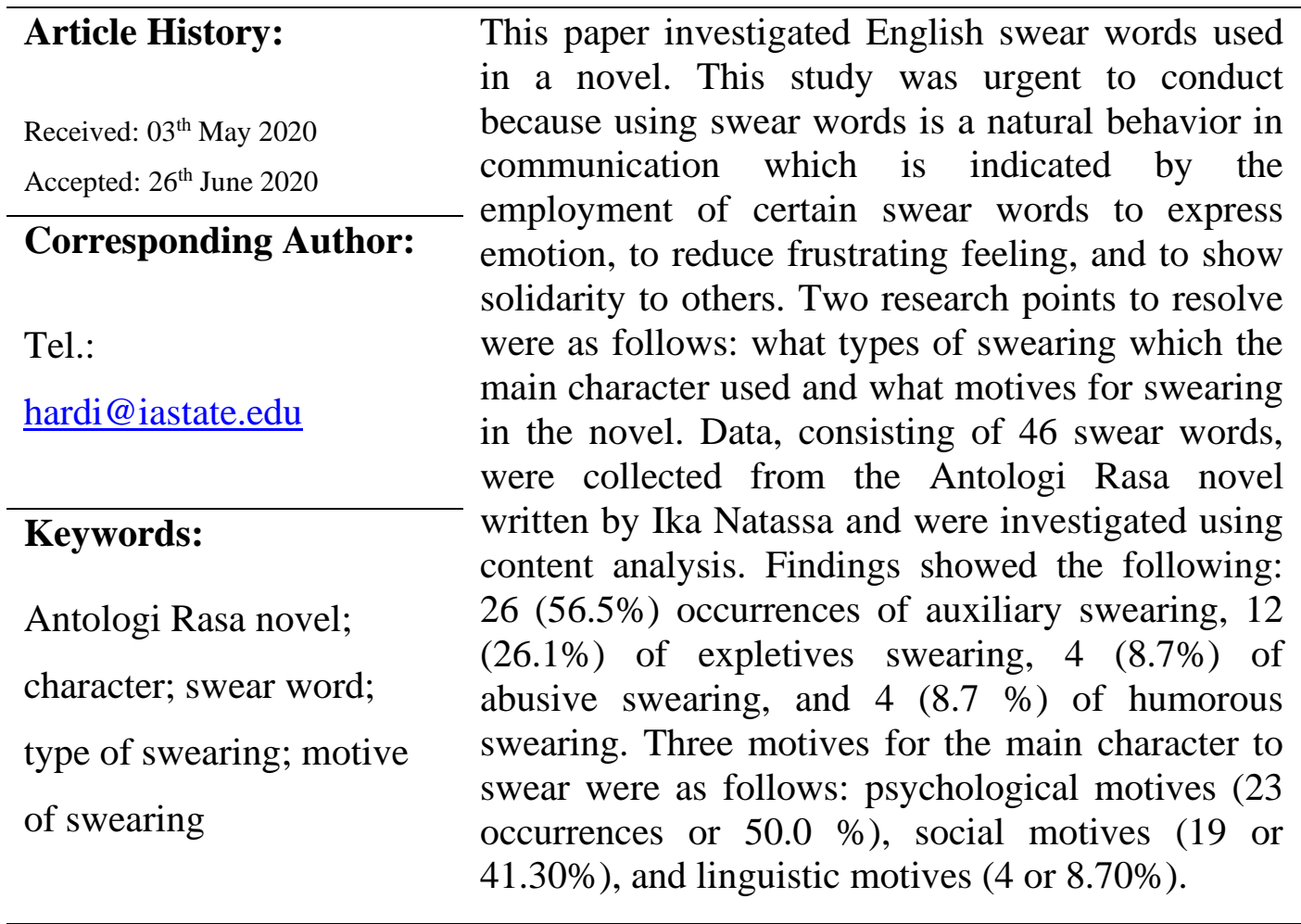

\section{INTRODUCTION}

A novel is one way of communication because in the novel the authors might write their idea through the stories and let the readers guess the purposes of the stories. Dance states "communication intentionally is a situation in which a source transmits a message to the receiver with conscious intent to affect the 
latter's behavior" (as cited in Littlejohn \& Foss, 2011, p. 3). In novels, the authors are the sources who transmit their ideas of the stories as messages to the readers as the receivers. The messages can affect the readers'point of view or perception as the latter's behavior because the language has several functions while they are applied both in written or spoken. Chaika (1982, p. 2) argues that language is employed by individuals to expose or disguise their personality, yet they do not even recognize it. Moreover, people tend to utilize language variation to confirm their identity. Accordingly, people often employ words or language that might emphasize their strong feelings such as feeling upset, happy, or mad. In this case, several words which are thought to be bad language may be employed. In every culture, the use of bad language is mostly considered as inappropriate or impolite. However, each culture has a bad language and it must be different from one another. Expressing strong feelings can be noticed through the utterance of swear words. While swearing, people tend to use taboo words because it is considered as one of the strongest ways to release their emotions.

The term taboo was taken from Tongan language, tabu. Allan and Burridge (2006, pp. 2-3) define the word 'taboo' as a prohibited utterance, object, or behaviour. In other words, taboo behaviours are the activities which are considered inappropriate to do, while taboo words are the words which are seen as impolite words to be uttered, depending on the community they belong to. Firman (2009, p. 27) argues that taboo words and taboo behaviours are connected as some taboo behaviours are also included in the list of taboo utterances, yet not all of them. One of the common examples is that the term "motherfucker" which represents sexual intercourse between family members. This sexual intercourse is considered taboo in every society. It can be seen that this example is in line with the statement mentioned by Firman (2009) that some taboo activities are also taboo words. Another example, doing sexual activity in a proper place and situation is not prohibited for legal marriage. However, many people still assume that having a conversation about sex itself is considered taboo, especially in a certain community. Accordingly, it can be seen that almost all of the words that represent taboo behaviours are mostly categorized into taboo words (Allan \& Burridge, 2006, p. 2; see also Kristiano \& Ardi, 2018; Bram \& Putra, 2019).

Adityo Prawinanto

LET: Linguistics, Literature and Language Teaching Journal Vol. 10 No. 12020 
People tend to use some taboo words to swear while swearing itself is also considered as taboo act or attitude. Related to that case, it must be underlined that every word used to swear is a taboo word, but not every taboo word can be used to swear. Besides, taboo words are often seen as unacceptable utterances, thus they should be avoided language users around the world. It depends on the culture or society they belong to because people have the right to speak everything they want. This is called freedom of speech. As Pinker (2007, p. 1) states, "freedom of speech is the foundation of democracy because without it citizens cannot share their observations on folly and injustice or collectively challenge the authority that maintains them". However, still freedom of speech will not always be approved in every condition. In practice as well as in theory, the prosecution of obscene speech is just like a puzzle. Throughout history, some people have been killed for criticizing their leaders and it becomes the fate of freethinkers in many parts of the world (Pinker, 2007, pp. 1-2).

In a sociolinguistic study, the use of taboo and swear words belongs to the language variation topic. The use of language variation discussed in sociolinguistics is one of the common language phenomena in society. Yule (2010, p. 254) states that sociolinguistics, which is included in the linguistics field, concerns over the relationship of language and all aspects in society, including norms and any social phenomena. Trudgill (2000, p. 32) also mentions that sociolinguistics focuses on the effects of cultural phenomena to the speaking behavior. In this case, it can be seen that social context is always attached while investigating one's speaking behavior. Hence, the use of taboo and swear words is discussed in the sociolinguistic field. The language phenomenon related to the use of swearwords in society might be easily found in daily life, films, novels, and other literary works. Considering several facts that swearwords are easily found in the social life, it can be learned that many people assume that using swearwords in the real life is normal behavior as it might be used to release strong feelings verbally instead of physically.

In this study, the researchers discussed the swear words collected from the Antologi Rasa novel. The main reason for choosing the swear words as the topic was because swearing is considered as a natural behavior in communication. In 
this case, people tend to employ some taboo words while swearing. Another reason for the researchers chose swear words as the topic of the study was because the researchers found that some of the students in the English Language Education Study Program (ELESP), Sanata Dharma University, use English swear words in the daily conversation such as fuck, shit, and hell. The problem was that most ELESP students are non-native English speakers, but they use English swear words in daily communication. It has the same case as the swear words used in one of the Indonesian novels, Antologi Rasa. The four characters in the novel are also Indonesian people. In other words, they are non-native English speakers, but they use English swear words in a certain situation. From that case, the researchers intended to investigate the classification of swear words and also the possible reasons why people swear in English, through analyzing the swear words obtained in the Antologi Rasa novel, which are used by the main character. Considering the similarity of the context mentioned above, the researchers were interested to use a novel as the object of the research to discuss one of the types of written communication. The novel entitled Antologi Rasa, which was written by one of the famous novelists in Indonesia, Ika Natassa, was chosen. The main character was chosen because there are no differences among the swear words which are used by the other characters. Therefore, the main character can be representative of the other characters.

This study is distinct from the previous study as the researchers used a printed book, namely novel. While the previous studies analyzed the use of swear words existing in the movies. Bram and Putra (2019) analyzed the use of swear words in The Wolf of Wall Street movie. The swear words that appeared in this movie were analysed based on Pinker's (2007) typology. Another study concerning with the swear word topic was also conducted by Setiawan (2016). He analysed the $21^{\text {st }}$ Jump Street movie and employed a discourse analysis method in his study. In his research, he found six types of swearing, namely cursing, profanity, blasphemy, taboo or obscenity, insult and slurs, and scatology. Setiawan (2016) also reported that there were three motives for swearing in the movie. The main theory used to analyse the swear words in this study were different from the main theory used by those two studies. Besides, the researchers considered that the language used in the written text, such as in the novel, is more 
detailed and well-structured in terms of the context. Accordingly, the data presented in this study were more detailed and comprehensive.

Possessing a sufficient understanding of English swearwords is needed for non-native English speakers, especially English learners. Both the non-native English speakers and English learners need to understand the classification of swearing utterances and the motives why some people swear while having a conversation. Some theories related to swear words will be discussed further in the literature review to support the researchers' idea in conducting this research.

In the Antologi Rasa novel, the examples of swear words that mostly appear are fuck, hell, and shit as in the following sentences, "Welcome to my fucked up life, darling." (p. 18) and "What did I do wrong to be stuck in this shitty place?! " (p. 19). The researchers regarded that it is weird that the nonnative English speakers employ some swearwords if they have no sufficient knowledge related to the reasons why some native speakers are swearing. This is why the researchers were interested to conduct research on swear words deeper in the novel so that it enables the readers of this paper and the Antologi Rasa novel itself to have a deeper understanding about the use and the application of swear words in their communication skill both in written and in spoken expression.

In this paper, the researchers formulated two questions. First, what swear words are used by the main character in the Antologi Rasa novel? Second, what are the motives for the main character to swear in the novel?

Types of Swearing

Anderson and Trudgill (as cited in Lindahl, 2008, p. 4) categorize swear words into four types. The types proposed by Anderson and Trudgill are the most frequently uttered types by many people around the world. In addition, every form of swear words represents its own nature as it is distinct from one another. Those four types are classified as follows: expletive, abusive, humorous, and auxiliary swearing. Every type of swearing will be elaborated further.

Expletive swearing

Expletive swearing is a type of swearing which is uttered without any intention to hurt someone else. Expletive swearing is commonly used to release 
strong feelings or emotions of happiness and unhappiness. This type of swearing has no exact meaning. The expressions such as Shit!, Damn!, Hell!, Fuck! are included in this swearing type.

\section{Abusive swearing}

On the contrary, the abusive swearing can be considered as the opposite of the expletive swearing. This type of swearing is mostly delivered to other people. In addition, the speakers normally insert both "name-calling" and an insulting utterance. It could not be denied that this expression is used to allege other people using verbal expression. Here are some utterances that belonged to the abusive type: Go fuck yourself!, You are a fucking idiot!, and Fuck you!.

\section{Humorous swearing}

The utterances included in the humorous swearing are generally addressed to other people. The main difference between humorous swearing and abusive swearing is the intention of the speakers who do not involve any negative emotions such as anger. This non-offensive swearing is employed to amuse others and is used in a certain community in which the members of the community have known one another. Furthermore, humorous swearing might bring the situation to be more enjoyable. One of the examples of this swearing type is "Get your ass in gear!".

\section{Auxiliary swearing}

This type of swearing is different from expletive, abusive, and humorous swearing. Auxiliary swearing is not directed to someone else. Besides, it is not uttered to complain about certain conditions. Emphasizing the intention is the only reason why people employ this swearing type. The terms such as "lazy speaking" and "non-emphatic way of speaking" are also frequently attached to this type of swearing. The phrases such as "That fucking song" and "This shitty place" are included in the auxiliary swearing.

Considering Jay's and Anderson and Trudgil's classification of the types are almost similar, the researchers of this study used Anderson and Trudgil's concept as the main theory to response the first formulated research problem 
about swearing categories as they are relevant to be implemented in investigating swearwords included in the novel.

\section{Motives of Using Swear Words}

Some people argue that using taboo words in speaking and even swearing itself need to be taken into account in the daily life. The person who likes to swear is often seen as an uneducated person. Accordingly, the knowledge about the reasons why people swear must be investigated and spread out to make people have sufficient understanding related to this behavior. Andersson classifies three reasons for swearing, namely psychological motives, social motives, and linguistic motives (as cited in Karjalainen, 2002, p. 26).

\section{Psychological Motives}

It could not be denied that in daily life, everything can always go wrong. Someone gets frustrated or even angry when an unexpected event occurs out of control. Complaining and expressing anger or emotion are the natural outcomes that are both consciously and unconsciously produced. The real example is that when someone stumbles over the rock, he/she will show reflex such as stamping out his/her toe. More often, someone unconsciously utters certain taboo or swear words at the same time. As Harran (2010, p. 3) states, swearing is one of the common reactions as a result of the unpredictable action to reduce tension. Emotion is always involved in the psychological motives, consequently, the physical or verbal reaction will unconsciously arise.

Furthermore, the impact of swearing is less harmful compared to physical harassment and can recover one's feelings (Montagu, 2001). Jay (2009, p. 155) also argues that in releasing certain emotions either happiness or unhappiness, people tend to express their feelings through swearing. Therefore, from those perspectives, it can be concluded that any variety of emotions expressed by someone verbally are categorized in the psychological motives of wearing.

\section{Social Motives}

Social motives of swearing are the common factors that happen, especially in a certain community, yet complex. While swearing, for instance, people tend to claim their existence by entertaining, implying intimacy, offending, and even 
shocking. Karjalainen (2002) claims one of the most frequently used motives in daily life is this social reason. Most importantly, people do not 'always' involve any negative feelings while uttering swearwords for these purposes.

Furthermore, this social consideration is mostly connected to people's interpersonal skills in a certain community. When people are having interactions, social contexts are always involved. Similarly, when the swearwords are employed by someone in his/her group, they might show different purposes depending on the social contexts (Holmes, 2013, p. 283). Accordingly, it can be concluded that there would be various reasons why someone swears while having interaction in a certain community regarding the social contexts involved.

\section{Linguistic Motives}

In reality, there are many perspectives related to language that encompass dialects, accents, and norms. Similarly, people also have different perspectives about the use of swear words in daily conversation. Some people argue that swear words are not supposed to be used in any situation. However, many people argue that swear words are still possible to use in the proper situation. Andersson (as cited in Karjalainen, 2002, p. 30) claims that everyone has their right to use any word they understand, but, most importantly, they can deliver their intentions properly and correctly. Here is the example, "What a very nice rocking chair" and "What a fucking nice rocking chair" are two statements that are tolerable depending on the situation someone is dealing with. In other words, someone has his/her manner in the way of delivering the messages by employing any words and even any linguistic formations.

In a nutshell, one of the main concepts of linguistic motives is that how the speakers express the utterances which is not addressed to someone else around. Besides, the speakers focus more on either the linguistic aspects of the subjects or the emphasis of what they want to convey. The last concept of linguistic motives is to indicate someone's speaking behavior in an everyday situation.

The concept of those three motives was applied as the main theory in answering the second research question related to the reasons or motives for swearing. Furthermore, another reference was also obtained from the previous study which was conducted by one of ELESP students. However, the previous 
research focused on the meanings and the offensiveness of swearing. While this research has a different focus, which is related to the types and the motives of swearing.

\section{METHOD}

In this study, the researchers employed a qualitative approach. Ary, Jacobs, and Razavieh (2002, p. 22) suggest that "Qualitative research focuses on understanding social phenomena from the perspective of the human participants in the study". Furthermore, this approach generally offers a rich interpretation of certain phenomena instead of providing statistical data. Therefore, the researchers are expected to provide more genuine evidence considering the main objective of the qualitative approach itself.

While conducting this study, the researchers also applied one of the qualitative techniques, namely content analysis, to analyze the data. Ary et al. (2002) mention that "Content Analysis is a technique that enables writers to study human behavior indirectly, through an analysis of their communication" (p. 472). Generally, the documents used in this technique encompass written documents such as books, novels, magazines, newspapers, articles, and even pictures. However, songs, videos, films, gestures, and speeches can also be analyzed.

In this study, the data were taken from the novel which was written by Ika Natassa. The title of the novel is Antologi Rasa. All the swear words uttered by the main character of the novel were collected and used as the primary data of the study. The data obtained from the novel were analyzed using a content analysis technique to respond to the research problems, which were related to the types and motives of swearing. The researchers considered that content analysis was the most relevant technique in this study as it helped them gain insight related to one of the language phenomena.

In analyzing the data, some stages were employed by the researchers. Firstly, read all the pages of the Antologi Rasa novel, and then, underlined the swear words which were used in the novel. The next step was to transcribe all the swear words that had been got from the novel. Then, the researchers classified the utterances which were used by the main character in the conversation with her friends or with herself (monologue). In responding to the two research problems 
that had been formulated, the researchers searched for some theories which were related to the topics discussed and then matched each classification of the utterances of swear words to those theories. After that, the researchers analysed the data and drew conclusions based on the theories used.

More importantly, the researchers had to undergo systemic research procedures in finalizing this research. The first step of accomplishing this research was choosing the novels that contain many swear word phenomena written in English. The novel chosen was Antologi Rasa. Next, the researchers determined the objectives of this research, defined some terms which were used in the research, restricted the analysis components, organized some relevant data such as synchronize the data and the theories used in this research, developed research background, constructed a sampling arrangement, designed coding for the classification, checked the reliability and validity by consulting to the linguistic experts, and the last one, analysed the data that had been classified and matched those data with some theories. After that, the researchers reported the result of the analysis and drew conclusions based on the analysed data.

\section{FINDINGS AND DISCUSSION}

Types of Swear Words

This part aims at finding the answer to the RQ 1 that had been formulated by the researchers. The first research question is related to the classification of swear words based on their types, which were used by the author in her novel, Antologi Rasa. In analyzing the classification of swear words used in the novel, the researchers used Anderson and Trudgill's theory that categorizes swear words into four types. Those types are expletive swearing, abusive swearing, humorous swearing, and auxiliary swearing. The analyzed data reveal 46 swearing utterances used by the main figure in the Antologi Rasa novel that appeared in certain pages. The swearing categories and the total number of the occurrence are presented in the following table.

Adityo Prawinanto

LET: Linguistics, Literature and Language Teaching Journal Vol. 10 No. 12020 
Table 4.1 Types of Swearing

\begin{tabular}{ccc}
\hline Types of Swearing & Quantity & Percentage (\%) \\
\hline Auxiliary Swearing (AUS) & 26 & $56.5 \%$ \\
Expletives Swearing (ES) & 12 & $26.1 \%$ \\
Abusive Swearing (AS) & 4 & $8.7 \%$ \\
Humorous Swearing (HS) & 4 & $8.7 \%$ \\
\hline Total & $\mathbf{4 6}$ & $\mathbf{1 0 0} \%$ \\
\hline
\end{tabular}

From the table above, the auxiliary swearing (AUS) type becomes the most frequently appeared type among the other types, and it is followed by the Expletives Swearing (ES) type which is often used in the novel. Besides, the Abusive Swearing (ABS) type and Humorous Swearing (HS) type have the same quantity and percentage. Those are the classification of swear words based on the types which are used by the main character, Keara, in the novel. Based on the findings related to the types of swearing above, the auxiliary swearing takes the first position because the main character employed the auxiliary swearing to intensify the things she intended.

\section{Motives for Swearing}

The motives for swearing used by the main character of Antologi Rasa novel on certain pages were classified into three reasons. Those three swearing reasons are psychological motives, social motives, and linguistic motives. The data presented in Table 4.2 shows the psychological motive has the highest percentage compared to the other two. Meanwhile, the linguistic motive is on the second and followed by social motive. Further explanation will be elaborated in the discussion. 
Table 4.2 Motives for Swearing

\begin{tabular}{ccc}
\hline Motives & Quantity & Percentage (\%) \\
\hline Psychological Motive (PM) & 23 & $50.00 \%$ \\
Linguistic Motive (LM) & 19 & $41.30 \%$ \\
Social Motive (SM) & 4 & $8.70 \%$ \\
\hline Total & $\mathbf{4 6}$ & $\mathbf{1 0 0 \%}$ \\
\hline
\end{tabular}

Based on the table related to the motives for swearing above, it can be seen that the psychological motives take place in the first position because the main character mostly employed the swear words which were influenced by emotion. Besides, those psychological motives appeared in the monologue. Therefore, it can be seen that while the main character talked to herself (monologue), it tends that she was influenced by the certain feelings such as anger, frustration, joy, regret, sadness, and surprise. However, in the novel, the main character was mostly influenced by surprising things while she employed swearing words.

\section{DISCUSSION}

The main character of the Antologi Rasa novel seems to be familiar with swearing utterances in everyday interaction as shown in the swearing occurrences presented in the findings. The researchers may not say that the employment of swearing words in the novel is merely restricted by social status as all the characters are from the same social status based on the story. All characters employ swearwords to show that they have a closed relation. This kind of situation can be found easily in the novel. However, as what had been stated before, the researchers only analyzed the swearwords uttered by the main figure. In addition, swearing expressions can be uttered by or addressed to people either from the same or different social classes. In the Antologi Rasa novel, most of the characters only swear to those who are from the same social class. One of the evidence of this act in the novel is that Keara as the main character swears to her best friend, Dinda, even though they come from the upper social status. The 
researchers might say that they are from the upper social because it is described in the novel that Keara and Dinda are working as bankers but in different offices.

As mentioned before, people from any social class can use swearing utterances while having interaction in society. As an example, someone who is from a high social class might address the swearwords to those from lower-class for certain purposes, and vice versa. However, such a phenomenon cannot be found in the novel because there are only four characters in the novel and they come from the same social status. Accordingly, to answer RQ 1 and RQ 2, the researchers presented the explanation and discussion below.

\section{Types of Swear Words}

As presented in the research results, 46 swearing utterances used by the main figure were found. The researchers categorized those results following the main theory used in this study, namely expletive, abusive, humorous, and auxiliary swearing. Furthermore, in analyzing those swearing utterances, the context was always attached by the researchers. In this section, the researchers concluded that the auxiliary type is the most frequently appeared type that is used by Keara as the main character. Anderson and Trudgill suggest that auxiliary swearing indicates someone's speaking behavior or is generally called as 'lazy speaking' (as cited in Lindahl, 2008, p. 4). This swearing type is mostly uttered using a non-emphatic tone. Besides, it is complementary, not addressed towards others. Based on this theory, Keara often uses auxiliary swearing because she uses those words to intensify something she is telling about. The words she uttered which are included in auxiliary swearing are not addressed to other characters in the novel. Besides, each type of swearing will be discussed below.

\section{Expletives Swearing}

The first swearing type that can be found in the novel is that expletive swearing. As stated in the literature review, Anderson and Trudgill describe that expletive swearing is never addressed to someone else, rather than expressing any feelings being experienced (as cited in Lindahl, 2008, p. 4). Here is the example of auxiliary swearing found in the novel. 
Pandangan matanya yang tajam ditutupi sunglasses Tag Heuer, produk yang di-endorsed oleh Kimi juga, pembalap favoritnya. Ganteng-ganteng atletis.

Craaaaap, I started to sound like one of his fans. Males banget.

(Monologue) Page 36

In the example of the monologue above, Keara is describing how Haris looks like. It can be seen at the end of the way she describes Haris gantengganteng atletis which means that Haris is like an athletic handsome guy. However, she describes it in her mind. After that, she realizes what she has done, If she is doing so, she is like one of Haris's fans. It is showed at the sentence 'Craaaaap, I started to sound like one of his fans'. In this monologue, the word 'Crap' is uttered, although it is only in her mind. In English, the word 'crap' has the same meaning as 'shit'. This word does not have any correlation with the following sentence. Therefore, the word 'crap' in this sentence does not have any specific meaning. It is not even directed to Haris or other characters in the novel. It is just employed to express shocked emotion while realizing that she is just like one of Haris's fans.

Another example of Expletives Swearing (ES) is in a dialogue. It is one of the short conversation containing swear words utterances while Keara and Haris are having a short vacation in Singapore.

Keara: "Oh, shiiit, Cosmopolitan-nya nendang gila."

Haris : "Slow down, Key."

(Dialogue) Page 78

In the dialogue above, Keara and Haris had arrived in Singapore. Haris is also one of Keara's best friends and at that time they were having a vacation in Singapore. After arrived in there, Keara was amazed by the condition of a certain city in Singapore. It seems so different from the situation in Indonesia. Here, the term 'shit' was uttered by Keara, as the main character of the novel, which was not directed to Haris or other characters in the novel. The word 'shit' was uttered by her to show that she feels amazed and shocked. In other words, joy and 
happiness are a strong feeling that she wanted to express. She likes having a vacation as well in this cosmopolitan country, Singapore.

\section{Abusive Swearing}

The second type found in the Antologi Rasa novel was abusive swearing. As Anderson and Trudgill mention, abusive swearing is mostly addressed to someone else. Besides, this type is used to insult and offense other people due to several purposes. The abusive swearing generally involves "name-calling" and other offensive utterances (as cited in Lindahl, 2008, p. 4). The following example illustrates the employment of the abusive swearing found in the novel.

"I've always been wanted by dozens and dozens of men, you didn't want me, you son of a bitch."

(Monologue) Page 82

In the monologue above, the type of abusive swearing is applied. Even though this is a monologue, the use of swear words, especially the type of abusive swearing is still possible. The phrase 'son of a bitch' is uttered by Keara as the main character to curse the man, Ruly, who she loves. In the novel, Keara falls in love with Ruly, however, unfortunately, Ruly does not give any special reaction which shows that he loves Keara. Therefore, with having full of frustrated feeling, she applied swear words to curse Ruly instead. However, she did not want to directly say so in front of Ruly. That is why she just tries to release her feeling by talking to herself. Here, the swear words 'son of a bitch' belong to abusive type, but it did not cause any insult.

"This, I could get used to. ... I am such as an angry yet pathetic little bitch, aren't I?"

(Monologue) Page 260

In the monologue above, she described that she could make men fall in love with her easily. It was shown how easy it was to get Panji's attraction. She even explained that she meets up three up to four times a week with Panji. At the same time, she also complained that it is only Ruly, the man who cannot fall in love with her. In this case, it can be seen that Keara meets up with Panji to forget about Ruly for a while. However, while meeting up with Panji, they did not just 
go somewhere such as watching a movie and having dinner. They behave like they are in a relationship. They are kissing one another, flirting, and doing activities which refers to sexual activity. Therefore, she realized that she is just like a pathetic bitch. She calls herself a bitch. The word 'bitch' is said by herself and directed to herself. Here, the swear word which was used by Keara is a bit different from the previous example. Even though it is a monologue, but it caused insult which means that the insulted expression will affect herself.

\section{Humorous Swearing}

The third swear word type found in the Antologi Rasa novel is humorous swearing. As has been stated by Anderson and Trudgill, humorous swearing is expressed to amuse other people in a very fun situation (as cited in Lindahl, 2008, p. 4). This swearing type might be addressed to someone else, yet it is not offensive. Here are the examples:

Too much politics for me. Ya kecuali dengan Dinda yang sama nggak mau repotnya. Just two cool bitches strutting their stuff hahaha.

(Monologue) Page 66

In the monologue above, Keara says that she likes going somewhere and doing anything with boys while she was studying in formal education. She thinks that having a close relation with girls is complicated, sometimes girls talks behind someone's back and gossiping. However, she has one mate which happens to be a girl who has the same thought like her, Dinda. She often calls Dinda as a bitch, but in this sentence, she calls Dinda and herself as two bitches. Keara and Dinda do not take it as a serious problem in calling one another as a bitch because they have a very close relation. The word 'bitch' does not refer to the word 'whore'. But it is uttered and expressed in a playful and humorous situation.

“Don't 'freud' me, bitch," kataku tertawa waktu Dinda menganalisis begitu.

(Dialogue) Page 186

In the dialogue above, Dinda is trying to find the main reason why Keara falls in love with Ruly. After knowing Dinda's opinion, Keara gives very short comment "Don't 'freud' me, bitch". Here, the swearing term "bitch" is uttered by 
Keara. In general, the word "bitch" is not acceptable in daily conversation in western culture. Somehow, it can be accepted if it is uttered towards friends in a certain community. The Keara's reaction here does not offense Dinda at all and she does not regard Dinda as the real bitch, which means 'whore'. Besides, she is laughing while giving that reaction. She does not give anger feelings while saying so. In this context, it seems that this is a very natural utterance between Keara and Dinda. It can be used to show the close relation and solidarity between Keara and Dinda. Therefore, after knowing Keara's reaction, Dinda is not angry with her.

\section{Auxiliary Swearing}

The auxiliary swearing was also found in the Antologi Rasa novel. Following the theory mentioned by Anderson and Trudgill, auxiliary swearing is generally employed to show someone's speaking behavior and is also considered as 'lazy speaking'. The non-emphatic tone also becomes the main characteristic of this type (as cited in Lindahl, 2008, p. 4). The researchers presented the examples involved in this type that was found in the novel as follows:

Keara: “Karena gue nggak tahu kenapa, Din, tapi gue lagi males aja mikirin si Ruly. I've got too much shit going on in my life since the whole Singapore thing ..."

(Dialogue) Page 100

This dialogue occurs between Keara and Dinda. It happens at Dinda's house. At that moment, Dinda asked Keara about Ruly. She wondered why Keara does not tell anything about Ruly as usual. While Keara herself does not want to tell anything about Ruly because she has so much problem in her mind, especially one of the unpleasant moments when she had a short trip to Singapore with Haris. It can be seen in the following sentence "I've got to much shit going on in my mind...". The swearing word 'shit' is uttered by Keara. This word does not use to curse Dinda or someone else. It is just used to substitute the case or problem she had faced during a vacation in Singapore. It is expressed in a non-emphatic tone. Another example of Auxiliary Swearing can be seen as follows:

Adityo Prawinanto

LET: Linguistics, Literature and Language Teaching Journal Vol. 10 No. 12020 
"But isn't it funny how the universe is playing with us? ... And it's fucking ESPN with a fucking soccer match on."

(Monologue) Page 203

In the monologue above, Keara and Panji were having an intimate conversation with one another in Keara's apartment. In this situation, Keara was able to forget her thought about Ruly, the man that she loves, for a while. Suddenly, her hand nudged the TV's remote on the table and the TV was on. Then, the soccer match appeared on the TV screen. It reminded Keara's mind about Ruly so that she called the soccer match as 'fucking soccer match'. The swear word uttered by her in this situation did not direct to another character, but it was expressed in a non-emphatic tone.

Finally, it can be concluded that the auxiliary type is commonly used by Keara as the main character because she uses swear words to emphasize something she is telling about and not to be addressed to another character.

Motives of The Use of Swear Words

Investigating the motives of swearing is one of the objectives in conducting this research. Meanwhile, it is also used to answer the RQ 2 that had been formulated. The researchers were able to find swearing utterances to be categorized based on the three motives, namely psychological, social, and linguistic motives. While interpreting the motives of swearing utterances found in the novel, the researchers always considered the contexts involved as it was an essential factor in the interpretation technique. For example, when the researchers concluded that certain utterances were involved in psychological motives, those swearing utterances had to include any strong emotional influence. In other words, the researchers were also motivated to ensure that there was no disruption of the other two motives such as linguistic and social motives.

In contrast, in determining the social motives of certain utterances, the researchers had to take into account several social factors that might involve. Those social factors were mostly related to how the main character interacts with other figures in the story. Social motives can be indicated also by the involvement of intimacy, identity, and even social distance. This concept was also employed 
by the researchers while examining the linguistic motives found in the story. The researchers had to analyze whether or not the influence of linguistic aspects was involved such as merely speaking behavior or only emphasizing the intention. Accordingly, it could not be denied that considering the context attached in every utterance is a necessary aspect to classify the swearing utterances found in the novel.

In this novel, the psychological reason is the most frequently appeared type which is used by the main character because while she is swearing, it is always influenced by her feelings such as anger, frustration, and happiness. Anderson (in Karjalainen, 2002, p. 26) stated that psychological motive is generally employed by someone to reduce tension or to express strong feelings being experienced. In this case, several feelings such as anger, frustration, and shock are included. Besides, each point of the three motives will be explained and discussed as follows.

\section{Psychological Motives}

The first motive that can be found in the Antologi Rasa novel is psychological motives. As suggested by Andersson, the psychological motive is spontaneously uttered by someone to reduce tension or to express strong feelings being experienced. One of the various types of emotions such as happiness, frustration, sadness, and others is generally involved (as cited in Karjalainen, 2002, p. 26). The swearing expressions that involve psychological motives in the novel are presented as follows.

$$
\begin{aligned}
& \text { Keara: "Oh, shiiit, Cosmopolitan-nya nendang gila." } \\
& \text { Haris : "Slow down, Key." }
\end{aligned}
$$

In the dialogue between Keara and Haris, the term 'shit' is verbally expressed by Keara indicating that she feels amazed and shocked. In other words, joy and happiness are a strong feeling that she wants to express. She likes having a vacation as well in this cosmopolitan country, Singapore. The following monologue is another example of Psychological Motives (PM): 
"But I can't help wondering, Rul, what is your weakness? ... crap, kenapa aku harus menyebut-nyebut nama si keparat itu lagi?"

(Monologue) Page 160

The swearing word 'crap' is uttered in this monologue by Keara. This monologue can be seen that Keara has not understood yet about Ruly's weaknesses. The setting of the monologue is on a beach. Keara and Ruly were hanging out together in the morning on a beach. At that time, they wanted to enjoy the morning by having relaxation on a beach. Keara wore a bikini and she wondered that Ruly was not tempted at all by what Keara wore. It is different from the other men who will be tempted by girls who wear a bikini in general, Haris, for instance. However, while she was remembering about Haris, she directly realized that she did not want to mention Haris's name anymore. Thus, while she is shocked, the swearing word 'crap' was uttered in her mind. It belongs to Psychological Motives (PM) because it has a strong relation with Keara's feelings. She cannot forgive Haris yet because he has raped Keara when Keara was drunk in a short trip to Singapore. She regrets to what Haris has already done to her.

\section{Social Motives}

Social motives are more relevant to the sociolinguistic concept as they are also dealing with the connectedness of language and society. When swearing expressions are employed in daily communication with someone else, swearing itself is seen as one of the speaking behaviors. However, taking into account the social context is more important to understand the intention of swearing utterances themselves. This is in line with the concept proposed by Andersson (in Karjalainen, 2002, p. 26) that swearing utterances might be employed to indicate the close relationship among the members of a certain community. In contrast, swearing expressions might also be uttered to insult other people due to several reasons in social life.

Based on the analysis, the data obtained in this research revealed that social motives are the least frequently appeared motives in the novel compared to the other two motives. The expressions involved in the social motives that were 
found in the novel are mostly affected by social impulsions. The examples of swearing utterances that include social motives are presented as follows:

Dinda: "Panji is not the asshole that we know then?"

Keara : "Oh, he IS the asshole that we know."

Dinda: "So he did try stuff with you?"

(Dialogue) Page 116

In the dialogue above, the swearing word 'asshole' is uttered by both Keara and Dinda. Asshole is the synonym of anus which means the opening where the gastrointestinal tract ends and exits the body (WebMD, 2014). In this dialogue, Keara and Dinda are mentioning Panji's name as an 'asshole'. They call him 'asshole' behind Panji's back. Remembering that Keara and Dinda have a very close relationship with one another, they call someone else as they want. It is only a matter of social interaction between those two characters. In fact, in the novel, Panji is not described as a real asshole. Furthermore, Keara and Dinda have never called Panji asshole when they meet.

The following monologue is another example of the use of a swear word which is influenced by the social motive (SM):

"Don't freud me, bitch," kataku tertawa waktu Dinda menganalisis begitu.

(Monologue) Page 186

In this monologue, Keara remembered that one day Dinda was trying to find out the reason why Keara felt in love with Ruly. Dinda said that Keare loves Ruly just because of Ruly's character who is mature. Besides, she regards that Ruly will always protect Keara as a father who always protects her daughters and sons. At that time, in her monologue, Keara says about her reaction while hearing Dinda's argument. It is not clear whether or not Keara agrees. However, based on the words she has uttered, the word 'bitch' appeared. Keara asked Dinda not to say so as if she knows everything about Keara. So, she calls Dinda's name using the word 'bitch' with no offense. The word "bitch" in this sentence is employed to show their close relationship with no anger expression or feeling.

Adityo Prawinanto

LET: Linguistics, Literature and Language Teaching Journal Vol. 10 No. 12020 


\section{Linguistic Motives}

The third motive found in the Antologi Rasa novel is linguistic motives. Anderson stated that linguistic motives are generally used to emphasize something that becomes the intention of the speakers (as cited in Karjalainen, 2002, p. 26). The linguistic motives found in the novel are mostly described to indicate that the main figure emphasizes something that she wants to talk about. Here are some examples included in the linguistic motives, which were taken from the story:

"Aku menahan diri untuk tidak muntah lagi sampai dia menghilang di balik pintu menuju dek. Fucking second jackpot."

(Monologue) Page 196

The monologue above occurs when Keara and Ruly are in the Port of Tanjung Benoa, together with the team of BorderBank and Wyman Parrish, to have dinner on Bounty Cruise. The dinner itself is arranged by the regional office Border of Denpasar as the last dinner in Bali before they go back to Jakarta. However, Keara gets seasick along the trip to the Port of Tanjung Benoa so that she decided to take a bottle of wine. After drinking some glasses of wine, she gets her first jackpot. In this context, jackpot means a situation in which someone vomits after drinking alcohol as what Keara did. Ruly knows what has happened to Keara and he tries to help her. He takes some painkillers for Keara. While Ruly is taking the painkillers for Keara, Keara talks to herself not to have her second jackpot in front of Ruly. Therefore, Keara employs swearing expression fucking second jackpot to herself to emphasize what she is talking about and something which she does not want it to happen in front of Ruly.

\section{Ruly : "Mendingan kan, ya, biasanya kalau udah minum obat begini?"}

Keara: “... I feel like I'm inside a crappy episode of The Love Boat.”

(Dialogue) Page 197

In this dialogue, Ruly had already taken medicine for Keara. Ruly asks Keara whether she feels better or not. Then Keara answered that usually, it will be better soon. However, while Keara rests on Ruly's shoulder, she hears a tune of music which she does not like at all. Then she talks to Ruly about it and calls this 
kind of situation like a very unpleasant episode of The Love Boat movie. However, she does not just mention it as an unpleasant episode, but a crappy episode. Here, the swearing word 'crap' is uttered to emphasize what she is talking about.

From the discussion, it can be concluded that the auxiliary type is the most common type that appears in the Antologi Rasa novel. It shows that the main character often uses swear words when she wants to emphasize something that she is talking about. While the most common motives used by the main character in the novel is psychological motives because while she is swearing, it is always influenced by her feelings, such as anger, frustration, shock, and surprise.

Based on the findings and discussion above, the researchers found that there were similarities and differences from the previous studies written by Bram and Putra (2019) and Setiawan (2016). Bram and Putra (2019) suggested that there were five types of swear words found in the movie, namely descriptive, idiomatic, cathartic, abusive, and emphatic swearing. Emphatic swearing is the most frequently used type in The Wolf of Wall Street movie. However, Bram and Putra (2019) did not analyze the motives of swearing in their study. Meanwhile, Setiawan (2016) reported that there were six types of swearing found in the $21^{s t}$ Jump Street movie, namely cursing, profanity, blasphemy, taboo or obscenity, insult, and slurs and scatology. Unfortunately, he did not mention the most dominant type used in the movie, but he also mentioned that there were three motives of swearing used in the movie. These three motives were the same as the motives used in this study. While the main difference between this study and those two previous studies was in the classification of swearing types due to the main theory used by each study.

\section{CONCLUSIONS AND SUGGESTIONS}

There are four swearing categories found in the Antologi Rasa novel, which were uttered by Keara as the main figure, namely Expletive Swearing (ES), Abusive Swearing (ABS), Humorous Swearing (HS), and Auxiliary Swearing (AUS). According to the research results, it can be concluded that the auxiliary swearing is the most frequently used category uttered by the main character of the novel as the swearing utterances she expresses are mostly complementary and are 
used to intensify the things she intended. Besides, those swearing expressions included in the auxiliary swearing category indicated her speaking behavior, even though the motives of those swearing utterances may be different.

Furthermore, the motives of swearing expressed by the main figure of the Antologi Rasa novel in certain parts can be used as the parameter of the analyzing process and determining the reasons for the swearing phenomena. Those motives are theoretically categorized into three motives. The first one is the Psychological Motive (PM), the second one is Social Motive (SM), and the last one is Linguistic Motive (LM). It can be concluded that the psychological motive (PM) is the most dominant motive used by the main figure while swearing. In other words, all the swearing words expressed by Keara are mostly influenced by her feeling and something to express her emotion such as joy, sorrow, shock and other feelings related to the psychological aspect.

Moreover, swearing expressions have become a daily conversation which is used by Keara in the novel. It becomes her way of speaking whether when she has a conversation with her friends (other characters in the novel) or even when the swearing words are not directed to others. However, she does not swear all the time in, though. The motives of the way she is swearing cannot be separated from the social context. Surely, she does not use any swearing words to anybody. She is still using a good language while she is with her mother and her boss, for instance. She uses swear words only to whom she has close relations, such as Dinda and Haris. She has never employed any swearing expression while talking to Panji and Ruly, even though those two men still swear. One of the important things in swearing is that the swear words or swearing expressions can be employed either constructive or destructive. On the one hand, the swearing expressions addressed to the other figures in the Antologi Rasa novel are mostly constructive as they are expressed to indicate a close and good relationship and also to entertain other figures. On the other hand, destructive swear words cannot be found in the novel.

\section{REFERENCES}

Akmajian, A., R. Demers, Farner, A., \& Harnish R. (2004). Linguistics: An introduction to language and communication. Cambridge, MA: Massachusetts Institute of Technology Press. 
Allan, K., \& Burridge, K. (2006). Forbidden words: Taboo and the censoring of language. Cambridge: Cambridge University Press.

Ary, D., Jacob, L.C., \& Razavieh, A. (2002). Introduction to research in education $\left(6^{\text {th }}\right.$ ed.). Belmont: Wadsworth Thomson Learning.

Battistella, E.L. (2005). Bad language: Are some words better than others? New York: Oxford University Press.

Bram, B., \& Putra, P. K. (2019). Swear words used by Jordan Belfort in the Wolf of Wall Street movie. SKASE Journal of Theoretical Linguistics, 16(2), 135-145.

Chaika, E. (1982). Language: The social mirror. Massachusetts: Newbury House Publishers.

Doyle, T.M (Ed.). (2006). Teaching "Bad Language" in a serious and systematic manner. Proceedings of the CATESOL State conference. Retrieved March 24, 2015, from http://www.catesol.org/06Doyle.pdf

Fairman, C.M. (2009). Fuck: Word taboo and protecting our first amendment liberties. Naperville, IL: Sphinx Publishing.

Fakuade, G., Kemdirim, N., Nnaji, I., \& Nwosu, F. (2013). Linguistic taboos in the Igbo society: A sociolinguistic investigation. Journal of Language, Discourse \& Society, 2(2),117-132.

Fraenkel, J.R., \& Wallen, N.E. (2008). How to design and evaluate research in education ( $7^{\text {th }}$ ed.). New York: McGraw-Hill.

Freitas, E.S.L. (2008). Taboo in advertising. Amsterdam: John Benjamins Publishing Company.

Freud, S. (1983). Totem and taboo. London: Routledge \& Kegan Paul.

Gill, R. (1997). Mastering English literature (4 ${ }^{\text {th }}$ ed.). London: Prentice-Hall.

Harran, T.J. (2010). The role of swearing in language. Department of Architecture and Mechatronics, Faculty of Engineering. Oita University. Retrieved March 24, 2015,from http://ir.lib.oitau.ac.jp/jspui/bitstream/

Holmes, J. (2013). An introduction to sociolinguistics (4 ${ }^{\text {th }}$ ed.). New York: Routledge

Jay, T. (1992). Cursing in America. Amsterdam: John Benjamins Publishing Company.

Jay, T., \& Kristin J. (2008). The pragmatics of swearing. Journal of Politeness, 4, 267-288.

Karjalainen, M. (2002). Where have all the swearwords gone? An analysis of the loss of swearwords in two Swedish translations of J. D. Salinger's 'Catcher in the Rye'. (Unpublished pro graduate thesis). Helsinki: University of Helsinki Press.

Adityo Prawinanto

LET: Linguistics, Literature and Language Teaching Journal Vol. 10 No. 12020 
Kristiano, J., \& Ardi, P. (2018). Swear words in Bad Boys II: A semantic analysis. LLT Journal: A Journal on Language and Language Teaching, 21(2), 191198. Retrieved from https://ejournal.usd.ac.id/index.php/LLT/article/view/1586

Lindahl, K. (2008). The $x$-word and its usage: Taboo words and swearwords in general, and $x$-words in newspapers. Retrieved December 25, 2015, from http://www.diva-portal.org/smash/record.jsf?

Littlejohn, S.W., \& Foss, K.A. (2011). Theories of human communication $\left(10^{\text {th }}\right.$ ed.). Long Grove, IL: Waveland Press.

Ljung, M. (2011). Swearing: A cross-cultural linguistic study. London: Palgrave Macmillan.

Mbaya, N. (2002). Linguistic taboo in African marriage context: A study of Oromo Laguu. Nordic Journal of African Studies. 11, 224-235.

Mercury, R.E. (1995). Swearing: A bad part of language; A good part of language learning. TESL Canada Journal, 13(1), 28-36. Retrieved January 12, 2015. http://files.eric.ed.gov/fulltext/EJ518119.pdf

Mikoluk, K. (2013). Types of communication: Verbal, non-verbal and written. Retrieved June 26, 2015, from https://blog.udemy.com/types-ofcommunication/

Moleong, L. J. (2001). Metode penelitian kualitatif. Bandung: PT Penerbit Remaja Rosdakarya.

Pinker, S. (2007). The seven words you can't say on television. London: Penguin Books.

Poggenpoel, M. \& Myburgh, C. (2003). The researcher as research instrument in educational research: A possible threat to trustworthiness?. Education Journal, 124.

Setiawan, M. A. (2016). Swear Words in 21st Jump Street Movie. (Doctoral dissertation, Sanata Dharma University).

Trudgill, P. (2000). Sociolinguistics: An introduction to language and society (4 ${ }^{\text {th }}$ ed.). London: Penguin Group.

Wardhaugh, R. (2006). An introduction to sociolinguistics (5 ${ }^{\text {th }}$ ed.). Oxford: Blackwell Publishing.

Yule, G. (2010). The study of language ( $4^{\text {th }}$ ed.). Cambridge: Cambridge University Press. 